This document was prepared in conjunction with work accomplished under Contract No. DE-AC09-96SR18500 with the U.S. Department of Energy.

This work was prepared under an agreement with and funded by the U.S. Government. Neither the U. S. Government or its employees, nor any of its contractors, subcontractors or their employees, makes any express or implied: 1 . warranty or assumes any legal liability for the accuracy, completeness, or for the use or results of such use of any information, product, or process disclosed; or 2 . representation that such use or results of such use would not infringe privately owned rights; or 3 . endorsement or recommendation of any specifically identified commercial product, process, or service. Any views and opinions of authors expressed in this work do not necessarily state or reflect those of the United States Government, or its contractors, or subcontractors. 


\title{
Full-Scale Testing of a Caustic Side Solvent Extraction System to Remove Cesium from Savannah River Site Radioactive Waste
}

\author{
M. R. Poirier \\ T. B. Peters \\ E. A. Brass \\ S. J. Brown \\ M. W. Geeting \\ L. C. Johnson, Jr. \\ C. J. Coleman \\ S. L. Crump \\ M. J. Barnes \\ S. D. Fink
}

October 15, 2007 
WSRC-STI-2007-00580

Revision 0

\section{SUMMARY}

Savannah River Site (SRS) personnel have completed construction and assembly of the Modular Caustic Side Solvent Extraction Unit (MCU) facility. Following assembly, they conducted testing to evaluate the ability of the process to remove non-radioactive cesium and to separate the aqueous and organic phases. They conducted tests at salt solution flow rates of 3.5, 6.0, and 8.5 gpm.

During testing, the MCU Facility collected samples and submitted them to Savannah River National Laboratory (SRNL) personnel for analysis of cesium, Isopar ${ }^{\circledR}$ L, and Modifier [1(2,2,3,3-tetrafluoropropoxy)-3-(4-sec-butylphenoxy)-2-propanol]. SRNL personnel analyzed the aqueous samples for cesium by Inductively-Coupled Plasma Mass Spectroscopy (ICP-MS) and the solvent samples for cesium using a Parr Bomb Digestion followed by ICP-MS. They analyzed aqueous samples for Isopar ${ }^{\circledR} \mathrm{L}$ and Modifier by gas chromatography (GC).

The conclusions from the cesium analyses follow.

- $\quad$ The cesium in the feed samples measured $15.8 \mathrm{mg} / \mathrm{L}$, in agreement with expectations.

- The decontamination factor measured 181 - 1580 at a salt solution flow rate of 3.5 gpm, $211-252$ at a salt solution flow rate of 6.0 gpm, and $275-878$ at a salt solution flow rate of $8.5 \mathrm{gpm}$.

- $\quad$ The concentration factor measured 11.0 - 11.1 at 3.5 gpm salt solution flow rate, 12.8 13.2 at $6.0 \mathrm{gpm}$ salt solution flow rate, and $12.0-13.2$ at $8.5 \mathrm{gpm}$ salt solution flow rate 
WSRC-STI-2007-00580

Revision 0

- The organic carryover from the final extraction contactor (\#7) varied between 22 and 710 $\mathrm{mg} / \mathrm{L}$ Isopar ${ }^{\circledR} \mathrm{L}$ The organic carryover was less at the lowest flow rate.

- The organic carryover from the final strip contactor (\#7) varied between 80 and $180 \mathrm{mg} / \mathrm{L}$ Isopar ${ }^{\circledR} \mathrm{L}$

- The organic carryover in the Decontaminated Salt Solution Hold Tank and the Strip Effluent Hold Tank was less than $10 \mathrm{mg} / \mathrm{L}$ Isopar ${ }^{\circledR} \mathrm{L}$, indicating good recovery of the solvent by the coalescers and decanters.

\section{INTRODUCTION}

The Department of Energy identified the Caustic Side Solvent Extraction (CSSX) process as the preferred technology for removing cesium from radioactive waste solutions at the Savannah River Site (SRS). ${ }^{1,2}$ As a result, the Washington Savannah River Company (WSRC) designed and built the MCU facility in the SRS Tank Farm to process liquid waste for an interim period until the Salt Waste Processing Facility (SWPF) begins operations.

In the CSSX process (see Figure 1), solvent contacts SRS liquid salt waste in centrifugal contactors. During contact, cesium transfers from the aqueous phase (i.e., salt solution) to the solvent and the aqueous and organic phases are separated. The solvent is stripped of cesium by dilute nitric acid in subsequent contactors. Following separation of the strip solution from the solvent, the strip effluent is transported to the Defense Waste Processing Facility. The decontaminated aqueous salt solution is transferred via a piping system for ultimate disposal through the Saltstone Production Facility. The stripped solvent is washed with $0.01 \mathrm{M} \mathrm{NaOH}$ to 
WSRC-STI-2007-00580

Revision 0

prepare it for reuse in the process. The decontaminated salt solution and strip effluent solution will contain droplets of solvent that have not been separated in the centrifugal contactors. Because of the cost of the solvent and the adverse impacts on downstream facilities, SRS has installed coalescers and decanters downstream of the contactors to recover this solvent from these streams.

The solvent for this process contains four components. The extractant is a calixarene-crown ether, calix[4]arene-bis(tert-octylbenzo-crown-6), called BOBCalixC6. The solvent contains a Modifier, which is an alkyl aryl polyether, to keep the extractant dissolved in the solvent and increase its ability to extract cesium in the extraction section. The Modifier is 1-(2,2,3,3,tetrafluoropropoxy)-3-(4-sec-butylphenoxy)-2-propanol, and is called Cs-7SB. The solvent contains a suppressant, trioctylamine, which suppresses the effects of anionic organic impurities and improves the back-extraction of cesium from the solvent in the stripping section. The diluent is Isopar $^{\circledR} \mathrm{L}$, a mixture of branched hydrocarbons. ${ }^{3,4,5,6}$

SRS personnel have completed construction and assembly of the MCU facility. Following assembly, they conducted testing to evaluate the ability of the process to remove non-radioactive cesium and to separate the aqueous and organic phases.

They conducted the tests as follows. A vendor (Blue Line Chemical) prepared simulated SRS salt solution (see Table 1). MCU personnel added nonradioactive cesium to the salt solution to achieve a cesium concentration of $14.9 \mathrm{mg} / \mathrm{L}$ (equivalent to $1.1 \mathrm{Ci} / \mathrm{gal}{ }^{137} \mathrm{Cs}$ ). They processed the salt solution through the MCU process at flow rates of 3.5, 6.0, and 8.5 gpm (referred to as 
WSRC-STI-2007-00580

Revision 0

Tests A, B, and C, respectively). During the testing, they collected samples from the inlet and outlet of selected contactors to measure cesium removal from the salt solution, cesium transfer from the solvent to the strip acid, organic solvent carryover into the decontaminated salt solution and strip acid. They collected samples from the Decontaminated Salt Solution Hold Tank and Strip Effluent Hold Tank to measure the effectiveness of the coalescers in recovering solvent from the aqueous streams. Following the tests, they performed a solvent cleanup test in which they recycled decontaminated salt solution through the contactors to remove cesium from the solvent. Following that test, they stopped and restarted the MCU process to determine its ability to rapidly reestablish process efficiency after shutdown and restart.

\section{ANALYSES}

The authors performed the ${ }^{133}$ Cs analysis by ICP-MS. The aqueous samples (decontaminated salt solution and strip effluent) were submitted directly to the ICP-MS. The solvent samples were digested using a Parr Bomb Digestion prior to analysis by ICP-MS. They analyzed salt and strip samples for Isopar ${ }^{\circledR} \mathrm{L}$ and Modifier by gas chromatography with flame ionization detection (GC-FID) and gas chromatography-mass spectrometry (GC-MS).

The ICP-MS used for the analyses is a Thermo-Elemental Plasma Quad II. This instrument provides multi-element analyses of aqueous solutions, and the analytical results can be expressed as either elemental or isotopic concentrations. The instrument aerosolizes the sample and transports the aerosol to the argon plasma. In the high temperature plasma $\left(\sim 10,000{ }^{\circ} \mathrm{K}\right)$ metallic species are ionized. The ions generated by the plasma enter the mass spectrometer through a 
WSRC-STI-2007-00580

Revision 0

sampling cone set near the end of the plasma. The ions are separated by a quadrapole mass filter and focused on a detector. The detector provides either an ion count or an analog signal. The signal from the detector is amplified, measured, and stored in a multi-channel analyzer, and these measurements are used to calibrate the instrument and determine the concentrations of the elements of concern.

The authors performed the solvent sample digestions as follows. Approximately 0.1-0.2 $\mathrm{g}$ of the well-mixed sample was transferred to the Teflon ${ }^{\mathrm{TM}}$ cup of a Parr Bomb dissolution container. A $3 \mathrm{~mL}$ aliquot of high-purity concentrated nitric acid was added and the dissolution container sealed. Typically eight containers were heated simultaneously in an oven pre-heated to $175{ }^{\circ} \mathrm{C}$. Heating was continued for at least three hours after the oven temperature re-equilibrated to $175^{\circ} \mathrm{C}$. After cooling to room temperature, the containers were opened and the nitric acid solutions were diluted to $10 \mathrm{~mL}$ with de-ionized water. No immiscible organic fraction or solution cloudiness was evident after this treatment, indicating that the oxidation of the organic fraction in the samples was complete.

Personnel performed the GC-FID and GC-MS analyses as follows. They weighed the sample bottle. They either added hexane to the sample bottle (1/4 of sample volume) or transferred the sample to a larger bottle and rinsed the sample bottle with the hexane. They recorded the weight of the bottle, sample, and hexane. They removed the top layer of liquid and placed it in a vial with a Teflon ${ }^{\mathrm{TM}}$ cap. They recorded the empty bottle weight. They dried the hexane with sodium sulfate, collected aliquots, and analyzed them. 
WSRC-STI-2007-00580

Revision 0

GC-MS analysis or GC-FID analysis was employed to identify organic compounds in the samples. Analytical separations were carried out on a Hewlett Packard 6890 gas chromatograph, equipped with a $30 \mathrm{~m}$ DB-XLB column, with $0.18 \mathrm{~mm}$ diameter and $0.20 \mu$ film thickness for GC-MS. The GC-FID uses a $30 \mathrm{~m}$ DB-5ms column, with $0.2 \mathrm{~mm}$ diameter and $0.33 \mu$ film thickness. Quantification was performed using a Hewlett Packard 5973 mass selective detector. The mass spectrometer tuning was confirmed within 24 hours prior to each measurement using perfluorotributylamine.

\section{RESULTS}

\section{Cesium Removal}

Table 2 shows the analysis of the feed solution along with the control submitted. The feed cesium concentration measured $15.8 \mathrm{mg} / \mathrm{L}$ in both samples versus a target of $14.9 \mathrm{mg} / \mathrm{L}$. The $15 \mathrm{mg} / \mathrm{L}$ control sample measured $14.6 \mathrm{mg} / \mathrm{L}$ (3\% difference), well within the standard analytical uncertainty of $\pm 10 \%$. The analytical uncertainty on all measured values is $\pm 10 \%$, unless otherwise stated.

Table 3 shows the cesium concentration in the samples from the test conducted with a salt solution flow rate of 3.5 gpm. The Decontamination Factor (DF) varied between 181 and 1580, with an average value of 348. The Concentration Factor (CF) varied between 11.0 and 11.1. The cesium concentration in the solvent entering the extraction contactors was less than 1.1 $\mathrm{mg} / \mathrm{L}$, confirming effective cesium removal from the solvent during the stripping process. 
WSRC-STI-2007-00580

Revision 0

Table 4 shows the cesium concentration in the samples from the test conducted with a 6.0 gpm salt solution flow rate. The DF varied between 211 and 252, with an average value of 227. The CF varied between 12.8 and 13.2. The cesium concentration in the solvent entering the extraction contactors was less than $1 \mathrm{mg} / \mathrm{L}$, confirming effective cesium removal from the solvent during stripping, again.

Table 5 shows the cesium concentration in the samples from the test conducted with a 8.5 gpm salt solution flow rate. The DF varied between 275 and 878, with an average value of 470 . The CF varied between 12.0 and 13.2. The cesium concentration in the solvent entering the extraction contactors was less than $1 \mathrm{mg} / \mathrm{L}$, confirming effective cesium removal from the solvent by stripping, again.

Tables 6 and 7 show the cesium concentration in the samples collected during the Solvent Cleanup Test. Table 6 shows the cesium in the decontaminated salt solution samples. The cesium concentration decreased with time during this test, and all samples contained less than $0.2 \mathrm{mg} / \mathrm{L}$ cesium.

Table 7 shows the cesium concentration in the SHT. The cesium concentration measured less than $0.3 \mathrm{mg} / \mathrm{L}$. The solvent cesium concentration at the conclusion of the test with 8.5 gpm salt solution flow rate measured $0.21 \pm 0.16$. The initial solvent hold tank sample, collected 50 minutes after the start of the solvent cleanup test, had a cesium concentration of $0.030 \mathrm{mg} / \mathrm{L}$, 
WSRC-STI-2007-00580

Revision 0

showing a large fraction of the cesium had been removed from the solvent. Subsequent samples showed similar cesium concentrations. The last sample collected showed a higher cesium concentration. We are unsure of the reason for this increase. Given that the Salt Solution (see Table 6) did not show a similar increase in cesium, this result is likely due to analytical uncertainty.

Table 8 shows the cesium concentration in the decontaminated salt solution, strip effluent, and Solvent Hold Tank during the System Shutdown/Restart Test. In this test, the MCU system was shut down and restarted. The DF was 268, and the CF was 11.8. These results are consistent with the results from the Mass Transfer Tests. During the Mass Transfer Tests, the cesium in the decontaminated salt solution averaged $0.048 \pm 0.026 \mathrm{mg} / \mathrm{L}$, the cesium in the strip effluent averaged $194 \pm 15 \mathrm{mg} / \mathrm{L}$, and the cesium in the solvent averaged $0.40 \pm 0.31 \mathrm{mg} / \mathrm{L}$. The DF averaged $491 \pm 461$, and the CF averaged $12.2 \pm 0.9$.

Table 9 shows the cesium concentration in the inlet to Extraction Contactor \#1. The concentration is slightly higher than in the Salt Solution Receipt Tank (SSRT) and the Salt Solution Feed Tank (SSFT) (15.8 mg/L).

\section{Organic Carryover}

Table 10 shows the measured Isopar ${ }^{\circledR} \mathrm{L}$ concentration in aqueous samples collected from the outlet of Extraction Contactor \#7. The organic carryover varied between 22 and 709 mg/L Isopar $^{\circledR}$ L. The carryover measured during the test at 3.5 gpm was much less than measured 
WSRC-STI-2007-00580

Revision 0

during tests at higher salt solution flow rate $\left(31 \mathrm{mg} / \mathrm{L}\right.$ Isopar $^{\circledR}$ L versus $444-524 \mathrm{mg} / \mathrm{L}$ Isopar ${ }^{\circledR}$ L). This result is consistent with the results from the Integrated Test conducted previously, where the organic carryover was $\sim 80 \mathrm{mg} / \mathrm{L}$ Isopar ${ }^{\circledR} \mathrm{L}$ at salt solution flow rates of $3.5 \mathrm{gpm}$, and 130 - $100 \mathrm{mg} / \mathrm{L}$ Isopar ${ }^{\circledR} \mathrm{L}$ at flow rates of $4.5-8.5$ gpm salt solution.

Table 11 shows the measured Isopar ${ }^{\circledR} \mathrm{L}$ concentration in aqueous samples collected from the decontaminated salt solution hold tank (DSSHT). In all samples, the Isopar ${ }^{\circledR} \mathrm{L}$ concentration is less than $10 \mathrm{mg} / \mathrm{L}$. These results show that the coalescer and decanter effectively recovered solvent from the decontaminated salt solution.

Table 12 shows the measured Isopar ${ }^{\circledR} \mathrm{L}$ concentration in aqueous samples collected from the outlet of Strip Contactor \#7. The organic carryover varied between 80 and $182 \mathrm{mg} / \mathrm{L}$ Isopar ${ }^{\circledR}$ L. No significant difference in organic carryover was observed between the different tests. These results are consistent with the Integrated Test conducted previously, in which the organic carryover varied between 170 and $370 \mathrm{mg} / \mathrm{L} \operatorname{Isopar}^{\circledR} \mathrm{L}$.

Table 13 shows the measured Isopar ${ }^{\circledR} \mathrm{L}$ concentration in aqueous samples collected from the strip effluent hold tank (SEHT). In all samples, the Isopar ${ }^{\circledR} \mathrm{L}$ concentration is less than $10 \mathrm{mg} / \mathrm{L}$. The modifier concentration in SEHT was $18-29 \mathrm{mg} / \mathrm{L}$. The modifier concentration is higher than the Isopar ${ }^{\circledR} \mathrm{L}$ concentration due to the modifier's solubility in dilute nitric acid. Given that the average modifier concentration in the SEHT was $23.6 \mathrm{mg} / \mathrm{L}$, we estimate the solubility of modifier in strip acid to be $23.6 \mathrm{mg} / \mathrm{L}$. These results show that the coalescer and decanter effectively recovered solvent from the strip effluent stream. 
Subtracting the soluble Modifier from the measured Modifier in the Strip Effluent Contactor outlet samples, we calculate an insoluble Modifier concentration (see Table 12). Using the insoluble Modifier concentration, we calculate a modified Isopar ${ }^{\circledR}$ L:Modifier ratio, which varies between 1.72 and 2.49 with an average of 2.1. This average agrees well with the calculated Isopar $^{\circledR}$ L:Modifier ratio of 2.32 .

\section{CONCLUSIONS}

The conclusions from the cesium analyses follow.

- $\quad$ The cesium in the feed samples measured $15.8 \mathrm{mg} / \mathrm{L}$, in agreement with expectations.

- The decontamination factor measured 181 - 1580 at a salt solution flow rate of 3.5 gpm, $211-252$ at a salt solution flow rate of $6.0 \mathrm{gpm}$, and $275-878$ at a salt solution flow rate of $8.5 \mathrm{gpm}$.

- $\quad$ The concentration factor measured 11.0 - 11.1 at 3.5 gpm salt solution flow rate, 12.8 13.2 at 6.0 gpm salt solution flow rate, and $12.0-13.2$ at 8.5 gpm salt solution flow rate

- The organic carryover from the final extraction contactor (\#7) varied between 22 and 710 mg/L Isopar ${ }^{\circledR} \mathrm{L}$ The organic carryover was less at the lowest flow rate.

- The organic carryover from the final strip contactor (\#7) varied between 80 and $180 \mathrm{mg} / \mathrm{L}$ $\operatorname{Isopar}^{\circledR} \mathrm{L}$

- The organic carryover in the Decontaminated Salt Solution Hold Tank and the Strip Effluent Hold Tank was less than $10 \mathrm{mg} / \mathrm{L}$ Isopar $^{\circledR} \mathrm{L}$, indicating good recovery of the solvent by the coalescers and decanters. 
WSRC-STI-2007-00580

Revision 0

\section{REFERENCES}

1. C. L. Huntoon to G. P. Rudy, memorandum titled "Preferred Alternative for the Savannah River Salt Processing Project”, June 25, 2001.

2. R. A. Dimenna, H. H. Elder, J. R. Fowler, R. C. Fowler, M. V. Gregory, T. Hang, R. A. Jacobs, P. K. Paul, J. A. Pike, P. L. Rutland, F. G. Smith III, S. G. Subosits, G. A. Taylor, S. G. Campbell, and F. A. Washburn, "Bases, Assumptions, and Results of the Flowsheet Calculations for the Decision Phase Salt Disposition Alternatives”, WSRC-RP-99-00006, Rev. 3, May 24, 2001.

3. R. A. Leonard, S. B. Aase, H. A. Arafat, C. Conner, D. B. Chamberlain, J. R. Falkenberg, M. C. Regalbutto, and G. F. Vandegrift, "Experimental Verification of Caustic-Side Solvent Extraction for Removal of Cesium from Tank Waste”, Solv Ext Ion Exchange, vol. 21, No. 4, pp. 505-526, 2003.

4. W. R. Wilmarth, J. T. Mills, V. H. Dukes, M. C. Beasley, A. D. Coleman, C. C. DiPrete, and D. P. DiPrete, "Caustic-Side Solvent Extraction Batch Distribution Coefficient Measurements for Savannah River Site High-Level Wastes”, Sep. Sci. Tech., vol. 38, No. 12-13, pp. 2637-2645, 2003.

5. M. A. Norato, M. H. Beasley, S. G. Campbell, A. D. Coleman, M. W. Geeting, J. W. Guthrie, C. W. Kennel, R. A. Pierce, R. C. Ryberg, D. D. Walker, J. D. Law, and T. A. Todd, "Demonstration of the Caustic-Side Solvent Extraction Process for the Removal of ${ }^{137}$ Cs from Savannah River Site High Level Waste”, Sep. Sci. Tech., vol. 38, No. 12-13, pp. 2647-2666, 2003.

6. P. V. Bonnesen, L. H. Delmau, and B. A. Moyer, "A Robust Alkaline-Side CSEX Solvent Suitable for Removing Cesium from Savannah River High Level Waste”, Solv. Ext. Ion Exch., vol. 18, No. 6, pp. 1079-1107, 2000. 
WSRC-STI-2007-00580

Revision 0

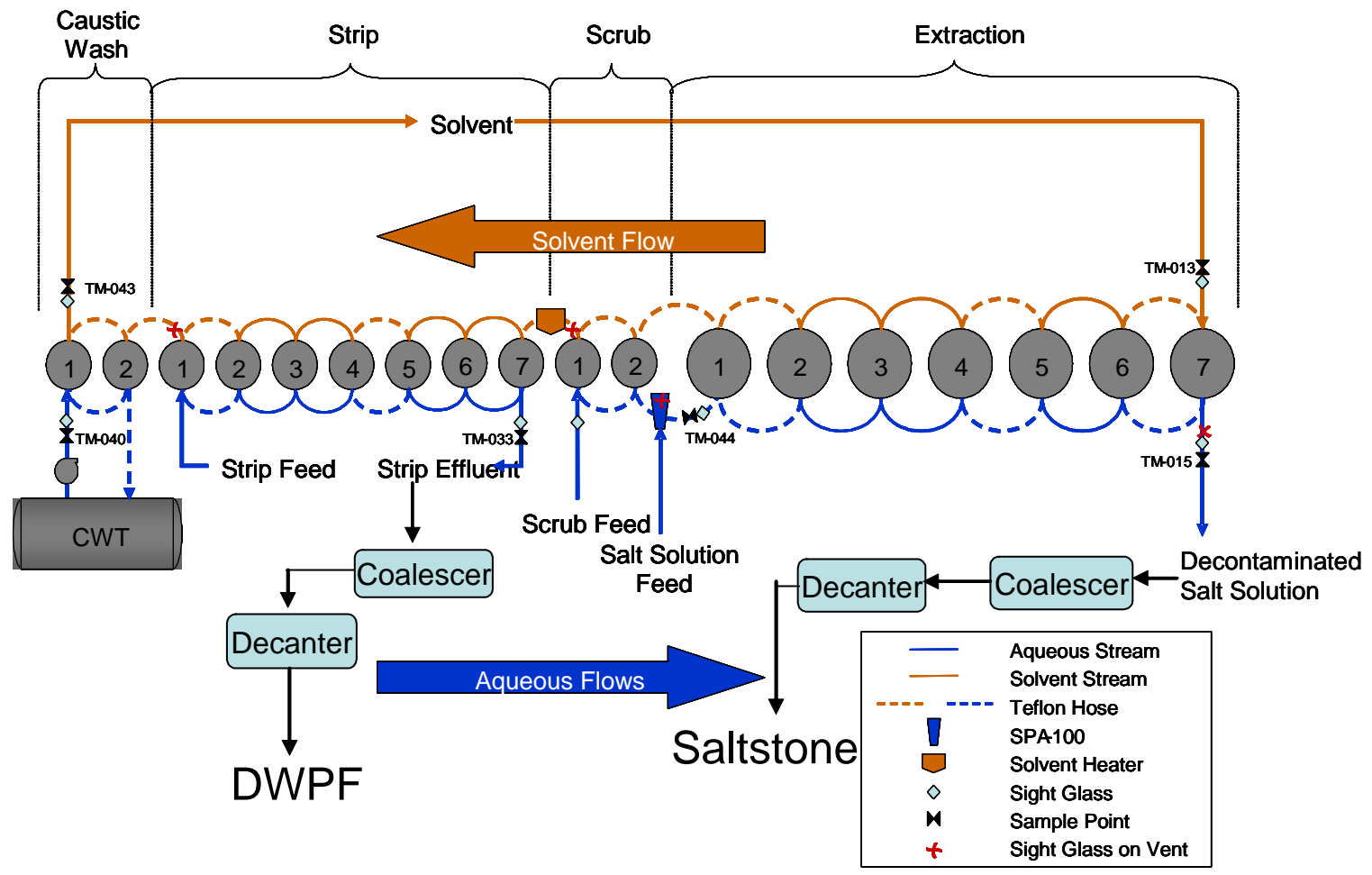

Figure 1. Solvent Extraction Contactor Layout 
Table 1. SRS Simulated Salt Solution Composition

$\underline{\text { Species }}$

$\mathrm{KNO}_{3}$

$\mathrm{NaOH}$

$\mathrm{NaNO}_{3}$

$\mathrm{NaNO}_{2}$

$\mathrm{NaAlO}_{2}$

$\mathrm{Na}_{2} \mathrm{CO}_{3}$

$\mathrm{Na}_{2} \mathrm{SO}_{4}$

$\mathrm{NaCl}$

$\mathrm{NaF}$

$\mathrm{Na}_{2} \mathrm{HPO}_{4}$

$\mathrm{Na}_{2} \mathrm{C}_{2} \mathrm{O}_{4}$

$\mathrm{Na}_{2} \mathrm{SiO}_{3}$

$\mathrm{Na}_{2} \mathrm{MoO}_{4}$
Concentration (Molar)

0.015

2.07

2.02

0.50

0.28

0.15

0.14

0.024

0.028

0.007

0.008

0.030

0.00007 
Table 2. Feed Solution Cesium Concentration

Sample $\quad$ Cesium (mg/L)

MCU-CS-I-SSRT 15.8

MCU-CS-I-SSFT 15.8

15 mg/L Control 14.6 
Table 3. Cesium Concentration (mg/L) during Test with 3.5 gpm Salt Solution Flow Rate

\begin{tabular}{|c|c|c|c|c|c|c|}
\hline & Feed & $\underline{\text { DSS }}$ & $\underline{\mathrm{SE}}$ & $\underline{\text { Solvent }}$ & $\underline{\mathrm{DF}}$ & $\underline{\mathrm{CF}}$ \\
\hline MCU-CS-I-SSRT & 15.8 & & & & & \\
\hline MCU-CS-I-SSFT & 15.8 & & & & & \\
\hline MCU-CS-A-EC-A-O-1 & & $<0.010$ & & & & \\
\hline MCU-CS-A-EC-A-O-2 & & 0.017 & & & & \\
\hline MCU-CS-A-EC-A-O-3 & & 0.069 & & & & \\
\hline MCU-CS-A-EC-A-O-5 & & 0.087 & & & & \\
\hline MCU-CS-A-EC-A-O-6 & & 0.044 & & & & \\
\hline MCU-CS-A-SC-A-O-1 & & & 174 & & & \\
\hline MCU-CS-A-SC-A-O-3 & & & 176 & & & \\
\hline MCU-CS-A-SC-A-O-5 & & & 174 & & & \\
\hline MCU-CS-A-EC-O-I & & & & 1.062 & & \\
\hline MCU-CS-A-EC-O-I-1 & & & & 0.209 & & \\
\hline MCU-CS-A-EC-O-I-3 & & & & 0.849 & & \\
\hline MCU-CS-A-EC-O-I-5 & & & & 0.400 & & \\
\hline MCU-CS-A-EC-O-I-6 & & & & 0.588 & & \\
\hline Minimum & & $<0.010$ & 174 & & 181 & 11. \\
\hline Maximum & & 0.087 & 176 & & 1580 & 11.1 \\
\hline Average & & 0.045 & 175 & & 348 & 11. \\
\hline Standard Deviation & & 0.033 & 1.1 & & & \\
\hline
\end{tabular}


Table 4. Cesium Concentration (mg/L) during Test with 6.0 gpm Salt Solution Flow Rate

MCU-CS-I-SSFT

$\underline{\text { Feed }}$ SE

$\underline{\text { Solvent }}$

$\underline{\mathrm{DF}}$

$\underline{\mathrm{CF}}$

MCU-CS-B-EC-A-O-1

15.8

MCU-CS-B-EC-A-O-3

MCU-CS-B-EC-A-O-5

MCU-CS-B-SC-A-O-1

MCU-CS-B-SC-A-O-3

MCU-CS-B-SC-A-O-5

MCU-CS-B-SC-A-O-6

MCU-CS-B-EC-O-I

MCU-CS-B-EC-O-I-1

MCU-CS-B-EC-O-I-3

MCU-CS-B-EC-O-I-5

Minimum

Maximum

Average

Standard Deviation

0.075

0.071

0.063

204

202

209

207

0.749

0.227

0.214

0.191

$0.063 \quad 202$

$0.075 \quad 209$

$0.070 \quad 205.5$

0.006
211

252

227
12.8

13.2

13.0 
Table 5. Cesium Concentration (mg/L) during Test with 8.5 gpm Salt Solution Flow Rate

MCU-CS-I-SSFT

$\underline{\text { Feed }}$

$\underline{\mathrm{DSS}} \quad \underline{\mathrm{SE}}$

$\underline{\text { Solvent }} \underline{\mathrm{DF}}$

$\underline{\mathrm{CF}}$

15.8

MCU-CS-C-EC-A-O-1

15.8

MCU-CS-C-EC-A-O-3

0.057

MCU-CS-C-EC-A-O-5

0.032

MCU-CS-C-EC-A-O-6

0.028

MCU-CS-C-SC-A-O-1

0.018

MCU-CS-C-SC-A-O-3

208

190

MCU-CS-C-SC-A-O-5

199

MCU-CS-C-EC-O-I

MCU-CS-C-EC-O-I-1

MCU-CS-C-EC-O-I-3

MCU-CS-C-EC-O-I-5

MCU-CS-C-EC-O-I-6

Minimum

Maximum

Average

275

0.29

0.14

0.46

0.077

0.099

Standard Deviation

$\begin{array}{ll}0.018 & 190 \\ 0.057 & 208\end{array}$

$0.034 \quad 199$

$878 \quad 13.2$

$0.017 \quad 9$

$470 \quad 12.6$


WSRC-STI-2007-00580

Revision 0

Table 6. Cesium Concentration $(\mathrm{mg} / \mathrm{L})$ in Salt Solution during the Solvent Cleanup Test $\underline{\text { Sample }}$

MCU-CS-W-EC-A-I-1

MCU-CS-W-EC-A-I-3

Cesium (mg/L)

MCU-CS-W-EC-A-I-5 0.038

MCU-CS-W-EC-A-I-7 0.046

MCU-CS-W-EC-A-I-9 0.043 
WSRC-STI-2007-00580

Revision 0

Table 7. Cesium Concentration (mg/L) in Solvent Hold Tank during Solvent Cleanup Test $\underline{\text { Sample }}$

MCU-CS-SHT-1 Cesium (mg/L)

MCU-CS-SHT-3 $\quad 0.025$

MCU-CS-SHT-5 $\quad 0.037$

MCU-CS-SHT-7 $\quad 0.051$

MCU-CS-SHT-9 0.293

MCU-CS-SHT-11 0.851 
Table 8. Cesium Concentration during System Shutdown Test

Sample

MCU-CS-I-SSFT

MCU-CS-D-EC-A-O-1

MCU-CS-D-SC-A-O-1

MCU-CS-SHT-11
Sample

Feed

DSS

SE

SHT

DF

CF
Cesium (mg/L)

15.8

0.059

187

0.851

268

11.8 
Table 9. Cesium Concentration (mg/L) in Inlet to Extraction Contactor \#1

Sample

MCU-CS-A-EC-A-I

MCU-CS-B-EC-A-I

MCU-CS-C-EC-A-I

MCU-CS-I-SSRT

MCU-CS-I-SSFT

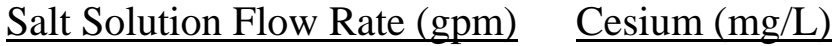

$\begin{array}{ll}3.5 \mathrm{gpm} & 16.8 \\ 6.0 \mathrm{gpm} & 16.9 \\ 8.5 \mathrm{gpm} & 18.3 \\ & 15.8 \\ & 15.8\end{array}$

16.8

16.9

18.3

15.8 
Table 10. Isopar $^{\circledR}$ L concentration in Extraction Contactor \#7 Outlet

$\underline{\text { Sample ID }}$

MCU-ISO-A-EC-A-O-1

MCU-MS-1

MCU-ISO-A-EC-A-O-3

MCU-MS-3

MCU-ISO-A-EC-A-O-5

MCU-ISO-A-EC-A-O-6

MCU-MS-5

Average

Standard Deviation

MCU-ISO-B-EC-A-O-1

MCU-MS-7

MCU-ISO-B-EC-A-O-3

MCU-ISO-B-EC-A-O-5

Average

Standard Deviation

MCU-ISO-C-EC-A-O-1

MCU-ISO-C-EC-A-O-3

MCU-ISO-C-EC-A-O-5

Average

Standard Deviation $\frac{\text { Test }}{(\mathrm{gpm})}$

3.5

3.5

3.5

3.5

3.5

3.5

3.5

3.5

3.5

6.0

6.0

6.0

6.0

6.0

6.0

8.5

8.5

8.5

8.5

8.5
37.0

33.2

21.8

33.6

35.1

31.7

26.9

31.3

5.3

487

501.5

366.8

419.6

443.7

62.5

709.1

210.8

651.0

523.6

272.4
22.2

14.2

20.1

19.7

23.9

23.6

12.0

19.4

4.6

233

154.2

174.6

201.7

190.9

34.2

315.0

137.6

286.9

246.5

95.4
2.25

1.66

2.34

1.08

1.71

1.47

1.34

2.24

1.61

3.25

2.10

2.08

2.32

1.53

2.27

2.12
2.09 
Table 11. Isopar $^{\circledR} \mathrm{L}$ concentration in DSSHT

Sample ID

MCU-ISO-A-DT-A-1

MCU-ISO-A-DT-A-3

MCU-ISO-A-DT-A-5

MCU-ISO-A-DT-A-6

MCU-ISO-B-DT-A-1

MCU-ISO-B-DT-A-3

MCU-ISO-B-DT-A-5

MCU-ISO-B-DT-A-6

MCU-ISO-C-DT-A-1

MCU-ISO-C-DT-A-3

MCU-ISO-C-DT-A-5
Test (gpm)

3.5

3.5

3.5

3.5

6.0

6.0

6.0

6.0

8.5

8.5

8.5
Isopar $^{-1}$

$<3$

$<2$

$<2$

$<2$

$<2$

$<2$

$<3$

$<3$

$<2$

4.9

7.7
Modifier (mg/L)

$<3$

$<2$

$<2$

$<2$

$<2$

$<2$

$<3$

29.9

14.2

7.3

9.5 
WSRC-STI-2007-00580

Revision 0

Table 12. Isopar $^{\circledR} \mathbf{L}$ concentration in Strip Contactor \#7 Outlet

\begin{tabular}{|c|c|c|c|c|c|c|}
\hline Sample ID & $\begin{array}{l}\text { Test } \\
\text { (gpm) }\end{array}$ & $\begin{array}{l}\operatorname{Isopar}^{\circledR} \mathrm{L} \\
(\mathrm{mg} / \mathrm{L})\end{array}$ & $\begin{array}{l}\text { Modifier } \\
(\mathrm{mg} / \mathrm{L})\end{array}$ & $\begin{array}{l}\text { Isopar }^{\circledR} \\
\text { L/Modifier }\end{array}$ & $\begin{array}{l}\text { Insoluble } \\
\text { Modifier (mg/L) }\end{array}$ & $\begin{array}{l}\text { Mod. Isopar }{ }^{\circledR} \\
\text { L/Modifier }\end{array}$ \\
\hline $\begin{array}{l}\text { MCU-ISO- } \\
\text { A-SC-A-O-1 }\end{array}$ & 3.5 & 80.5 & 66.8 & 1.21 & 43.2 & 1.86 \\
\hline $\begin{array}{l}\text { MCU-ISO- } \\
\text { A-SC-A-O-3 }\end{array}$ & 3.5 & 145.7 & 108.2 & 1.35 & 84.6 & 1.72 \\
\hline $\begin{array}{l}\text { MCU-ISO- } \\
\text { A-SC-A-O-4 }\end{array}$ & 3.5 & 130.4 & 81.0 & 1.61 & 57.4 & 2.27 \\
\hline $\begin{array}{l}\text { MCU-ISO- } \\
\text { A-SC-A-O-5 }\end{array}$ & 3.5 & 181.8 & 96.7 & 1.88 & 73.1 & 2.49 \\
\hline $\begin{array}{l}\text { Average } \\
\text { Standard } \\
\text { Deviation }\end{array}$ & $\begin{array}{l}3.5 \\
3.5\end{array}$ & $\begin{array}{r}134.6 \\
42.0\end{array}$ & $\begin{array}{l}88.2 \\
18.1\end{array}$ & 1.53 & 64.6 & 2.07 \\
\hline $\begin{array}{l}\text { MCU-ISO- } \\
\text { B-SC-A-O-1 }\end{array}$ & 6.0 & 161.6 & 92.7 & 1.74 & 69.1 & 2.34 \\
\hline $\begin{array}{l}\text { MCU-ISO- } \\
\text { B-SC-A-O-3 }\end{array}$ & 6.0 & 158.3 & 89.9 & 1.76 & 66.3 & 2.39 \\
\hline $\begin{array}{l}\text { MCU-ISO- } \\
\text { B-SC-A-O-4 }\end{array}$ & 6.0 & 147.8 & 87.7 & 1.69 & 64.1 & 2.31 \\
\hline $\begin{array}{l}\text { MCU-ISO- } \\
\text { B-SC-A-O-5 }\end{array}$ & 6.0 & 167.8 & 112.0 & 1.50 & 88.4 & 1.90 \\
\hline Average & 6.0 & 158.9 & 95.6 & 1.66 & 72.0 & 2.23 \\
\hline $\begin{array}{l}\text { Standard } \\
\text { Deviation }\end{array}$ & 6.0 & 8.4 & 11.1 & & & \\
\hline $\begin{array}{l}\text { MCU-ISO- } \\
\text { C-SC-A-O-1 }\end{array}$ & 8.5 & 113.9 & 79.7 & 1.43 & 56.1 & 2.03 \\
\hline $\begin{array}{l}\text { MCU-ISO- } \\
\text { C-SC-A-O-3 }\end{array}$ & 8.5 & 98.4 & 74.9 & 1.31 & 51.3 & 1.92 \\
\hline $\begin{array}{l}\text { MCU-ISO- } \\
\text { C-SC-A-O-5 }\end{array}$ & 8.5 & 99.8 & 73.5 & 1.36 & 49.9 & 2.00 \\
\hline Average & 8.5 & 104.0 & 76.0 & 1.37 & 52.4 & 1.98 \\
\hline $\begin{array}{l}\text { Standard } \\
\text { Deviation }\end{array}$ & 8.5 & 8.6 & 3.3 & & & \\
\hline
\end{tabular}


Table 13. Isopar ${ }^{\circledR} L$ concentration in SEHT

Sample ID

MCU-ISO-A-ST-A-1

MCU-ISO-A-ST-A-3

MCU-ISO-A-ST-A-5

MCU-ISO-B-ST-A-1

MCU-ISO-B-ST-A-2

MCU-ISO-B-ST-A-3

MCU-ISO-B-ST-A-5

MCU-ISO-C-ST-A-1

MCU-ISO-C-ST-A-3

MCU-ISO-C-ST-A-5

Average
Test (gpm) Isopar ${ }^{\circledR} \mathrm{L}(\mathrm{mg} / \mathrm{L}) \quad$ Modifier $(\mathrm{mg} / \mathrm{L})$

3.5

3.5

3.5

6.0

6.0

6.0

6.0

8.5

8.5

8.5
$<3$

$<3$

$<3$

$<3$

$<3$

$<2$

$<3$

$<3$

$<3$

$<3$

$<3$
22.3

23.6

26.5

25.2

21.3

20.1

24.5

25.9

17.9

28.8

23.6 